\title{
Evaluation of the Prosthetic Alternatives on Stress Distribution in Atrophic Maxilla in all-on-Four Treatment Concept: A Three- Dimensional Finite Element Analysis
}

\author{
Sefa Kılı̧, $\mathbf{P h D}^{1}$, Tolga Külünk, PhD $^{2^{*}}$, Şafak Külünk, $\mathbf{P h D}^{2}$ \\ ${ }^{1}$ Vezirköprü Dental Hospital, Samsun, Turkey \\ ${ }^{2}$ Ondokuz Mayls University, Faculty of Dentistry, Department of Prosthodontics, Samsun, Turkey \\ *Corresponding Author: Dr. Tolga Külünk, Ondokuz Mayls University, Faculty of Dentistry, \\ Department of Prosthodontics, 55139, Atakum, Samsun, Turkey.Email: tkulunk@omu.edu.tr
}

\begin{abstract}
Introduction: Today various prosthetic materials for framework and veneer materials are currently available in implant treatment, each with advantages and disadvantages. Because of this wide range of materials, treatment plans require extra care to provide optimal biomechanics.
\end{abstract}

Objective: To evaluate the level of stress distribution in the implant, prostheses, and bone around the implants, designed according to All on Four treatment concept with different framework and veneering materials in atrophic maxilla that makes use of a three-dimensional (3D) finite element analysis (FEA).

Material and Methods: Five framework materials: zirconium ( $\mathrm{Zr}$ ), titanium (Ti), polyether ketone ketone $(P E K K)$, polyether ether ketone (PEEK), and fiber reinforced polymer (FRP) and also three types of veneering materials: porcelain $(P)$, acrylic resin $(A)$, and composite resin $(C)$ were evauated.

Results: Framework and veneering materials were seen to make a difference in bone and implants under stress. The increase in the elasticity modulus of the framework material led to the decrease in the stresses transmitted to the implant and the bone along with the increase in the stresses in the framework.

Conclusion: As the elasticity modulus of the material used in the framework and veneering increased, the risk for long-term success and survival in the implant and surrounding tissues decreased. It is thought that the use of $\mathrm{Zr}$ and Ti materials in the framework and the porcelain material in the veneering is more suitable.

Keywords: All on Four, Framework material, Finite element analysis

\section{INTRODUCTION}

Atrophic maxilla undergoes prosthetic rehabilitation, which is considered to be a clinical challenge due to low quality and quantity of the bones, high level of severity and complicacy of the re-absorption process in the bones as well as close link to the maxillary sinuses [1-4]. An assumption that atrophic edentulous maxilla can be effectively treated with the application of tilted implants parallel to the maxillary sinus anterior wall as a conservative medical solution has been confirmed [5-7]. The treatment of maxilla using tilted implants with the technique 'All-on-Four' [8] have been increasingly used.

The key basis of the applied technique is distal tilting by about $30^{0}-35^{0}$ of the most posterior implants to increase the contact between the implant and the bone, ensure better stability of the primer, placing longer implants. If the distal implants are tilted, the distribution of the load improves and the length of distal cantilever gets reduced. It is also possible to eliminate the required procedures of bone grafting or complicated surgeries; therefore, treatment gets less time-consuming and the treatment protocol becomes more cost-effective [9-12].

According to the clinical studies, it is possible to predict an all-on-four concept, which has a cumulative survival rate of implants equal to approximately $94.5-94.7 \%$. Prosthetic success rate was $97,8-99,2 \%[13,14]$. Despite high rates of prosthetic success, it is typically associated with such wide-spread issues as fracture of a porcelain crown, prosthetic fracture, loosening of the abutment, loosening of the prosthetic screw, as well as bruxism and other factors which cause overloading of the prosthesis [15]. 
It is crucial to take into serious consideration the material used for a prosthetic framework as it impacts the process of stress transmission to the peri-implant bone area and implant-support system. Those factors can play an essential role in restoration survival and produce an important effect on the distribution of bone stress around the implants [16].

According to some authors, it is reasonable to use such polymeric frameworks as polyether ketone ketone (PEKK), polyether ether ketone (PEEK), or polymers with fiber-reinforcement to replace the previously used cobalt-chromium $(\mathrm{Co}-\mathrm{Cr})$, titanium $(\mathrm{Ti})$, and zirconia $\left(\mathrm{ZrO}_{2}\right)$ as rigid frameworks with high elastic modulus. This suggestion is based on a wide range of benefits that polymeric frameworks have, in particular their shock absorbency, light weight, and inexpensiveness. The outputs of research have demonstrated that materials that have nonpolymeric or stiff high frameworks as elastic modulus have the capacity to ensure stress transmittance to the bone-implant interface at an increased level as they have no shock-absorbing qualities [17-19]. Despite this some of the researchers provided promising results [20-23].

Hence, definition of behavior that different frameworks and veneering materials have in 'All-on-Four' technique requires biomechanical studies. Finite element analysis (FEA) applied to biomechanics is a tool of extraordinary use demanded for numerical calculation of such aspects as deformations and stresses and evaluation of the mechanical behaviour that tissues and biomaterials have $[24,25]$.

One of the objectives of this study implied evaluation of the stress distribution in the implants, prostheses, and bone around the implants which were designed according to All on Four treatment concept with different frameworks and veneering materials in atrophic maxilla with the applied 3-D finite element analysis. The study had to test the following hypothesis: veneering material and prosthetic framework with the different elasticity modulus impact the stress produced on the peri-implant area.

\section{Material AND MethodS}

The basis for construction of atrophic maxilla in the solid model was the use of data obtained from CT (computed tomography) done with Orthocad CT scanner (3M Imtec Corp., Ardmore, USA) with further transference into the software of Rhinoceros 4.0 (Robert McNeel \& Assoc., Seattle, USA) and 3D-Doctor (Able Software Corp., Lexington, USA) for the generation of a three-dimensional finite maxilla element model.

Scanning of the bone level dental implants (4.3 X $13 \mathrm{~mm}$, Switzerland, Nobel Biocare) and multi-unit abutments $\left(0^{\circ}\right.$ and $30^{\circ}$, Switzerland, Nobel Biocare) was done to get 3D models using a 3D scanner (Activity 880, Smart Optics Sensortechnik GmbH, Bochum, Germany. 'Allon-Four' technique implied vertical placing of two mezial implants in the lateral incisor positions, while other two were set in the second premolar positions with distal tilting at a $30^{\circ}$ angle. Modeling of the framework $3 \mathrm{~mm}$ thick and $5.1 \mathrm{~mm}$ wide was followed with its placing $2 \mathrm{~mm}$ over the alveolar ridge that has $10 \mathrm{~mm}$ of cantilever length from distal implants. Modeling of a complete prosthesis was done with CAD software.

Table1. Properties of structures and materials used in the models. *Values provided by manufacturer.

\begin{tabular}{|l|l|l|}
\hline & $\begin{array}{l}\text { Young } \\
\text { Modulus } \\
\text { (GPa) }\end{array}$ & $\begin{array}{l}\text { Poisson's } \\
\text { Ratio }\end{array}$ \\
\hline Cortical bone & 13.7 & 0.30 \\
\hline Trabecular bone (D3) & 1.37 & 0.30 \\
\hline Titanium implant & 110 & 0.35 \\
\hline $\begin{array}{l}\text { Peek framework } \\
\text { (Juvora Dental, Germany) }\end{array}$ & $3.5^{*}$ & $0.36^{*}$ \\
\hline Titanium framework & 110 & 0.28 \\
\hline Zirconium framework & 205 & 0.22 \\
\hline $\begin{array}{l}\text { Pekk framework (Pekkton, } \\
\text { Switzerland) }\end{array}$ & $5.1 *$ & $0.25^{*}$ \\
\hline $\begin{array}{l}\text { Fiber reinforced polymer } \\
\text { framework (Trinia, USA) }\end{array}$ & $19.1^{*}$ & $0.22^{*}$ \\
\hline Acrylic resin & 2.7 & 0.35 \\
\hline Composite resin & 12 & 0.33 \\
\hline Porcelain & 68.9 & 0.28 \\
\hline
\end{tabular}

Constructing the process of discretization for the complete 3D models was associated with generation of mesh with the use of VRMesh Studio software (VirtualGrid Inc) on quadratic tetrahedral elements with 10 nodes. Each model used 98.349 nodes and 489.196 elements in total. The FEA software (Algor Fempro, Pittsburg, USA) obtained the transferred meshed models with homogeneous structures that have linear elasticity to be considered isotropic. The literature served as a source for the Poisson's ratio and Young's modulus for the materials (Table 1) $[15,16,19]$. 
Application of $150 \mathrm{~N}$ total load was done with a $30^{\circ}$ inclination obliquely in the palato-bubcal direction on the posterior teeth of each group (Fig. 1). Evaluation of the stress distributions in implant body and prosthetic frameworks was done with the use of equivalent analysis of von Mises stress, while the analysis of stress distribution in the trabecular and cortical bone was done on the basis of principal stresses at their minimum and maximum levels.

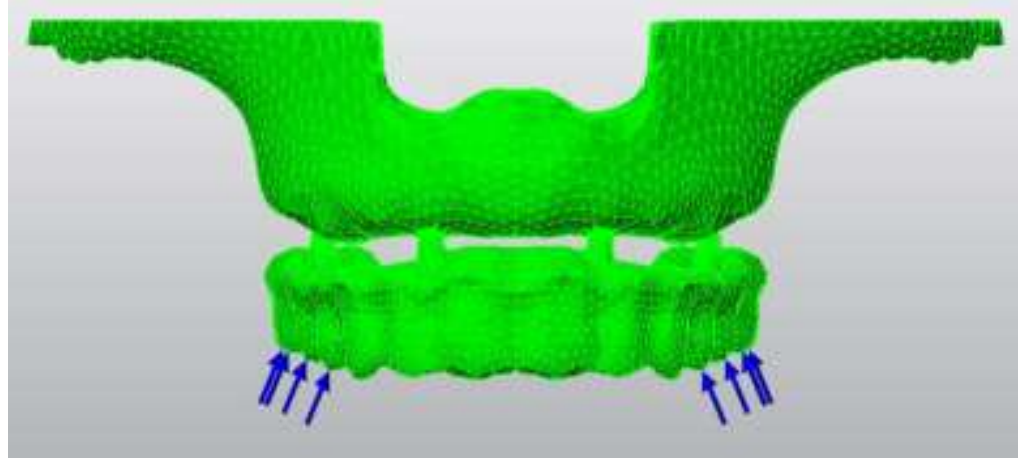

Fig.1. Oblique loading of $3 D$ model

\section{Results}

The stress peak values in each structure of all groups are shown in Fig.2.
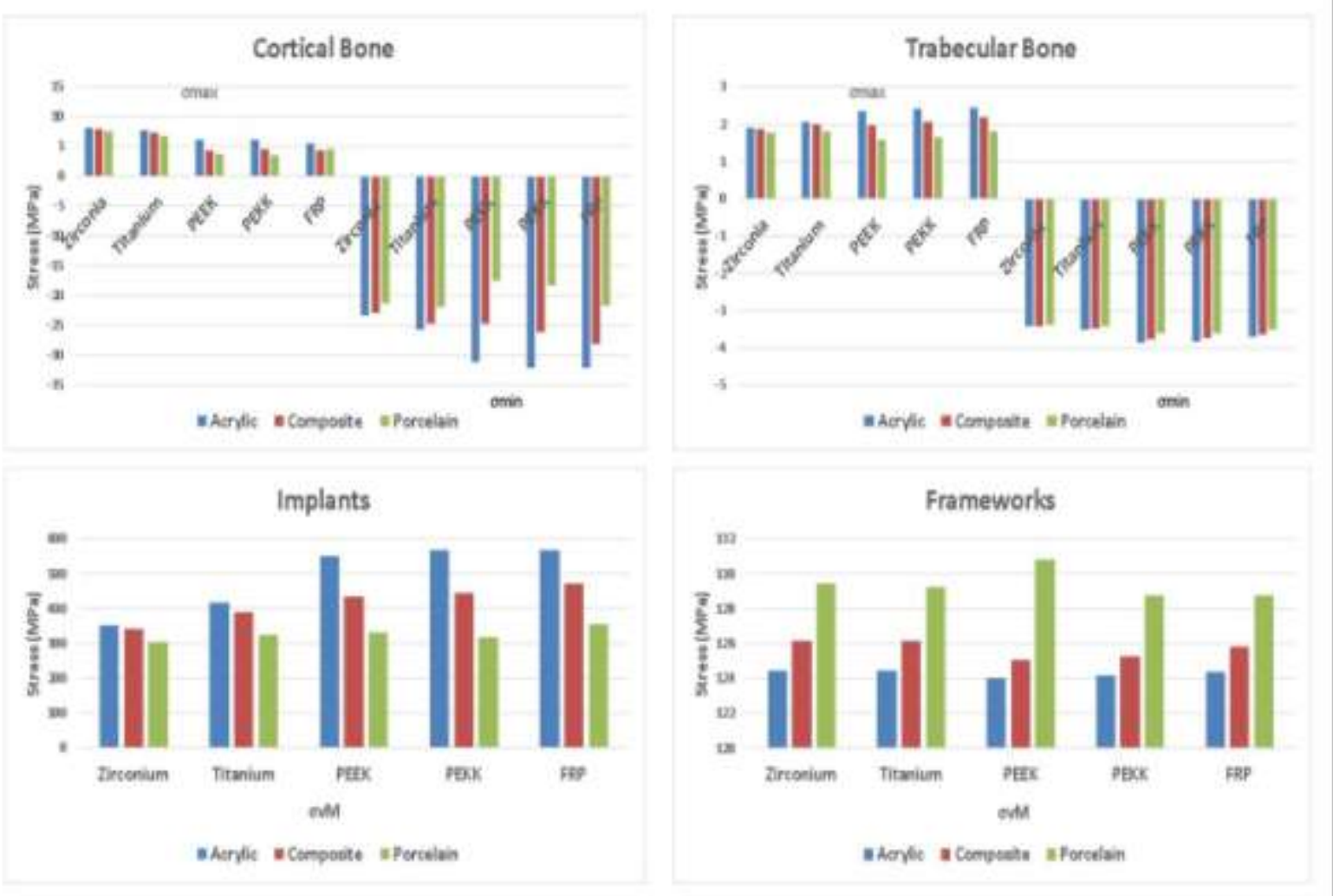

Fig.2. Stress values $(\mathrm{MPa})$ in maximum principal stress $\left(\sigma_{\max }\right)$, minimum principal stress $(\sigma \min )$ and von Mises stress $\left(\sigma_{v M}\right)$ for the cortical bone, trabecular bone, implants, and prosthetic framework in all groups

\subsection{Cortical Bone}

In acrylic groups, the highest maximum principal stress $(\mathrm{F}=8.10 \mathrm{MPa})$ was obtained in $\mathrm{Zr}$ groups, while Ti groups were the source from where the maximum principal stress at its lowest level ( $\mathrm{F}=0.36 \mathrm{MPa}$ ) was obtained (Fig.3). In composite groups, maximum principal stress at the highest level $(\mathrm{F}=7.94 \mathrm{MPa})$ was obtained from $\mathrm{Zr}$ groups, while the maximum principal stress at its lowest $(\mathrm{F}=0.38 \mathrm{MPa})$ was obtained from $\mathrm{Ti}$ groups (Fig.4). In porcelain groups, the maximum principal stress at its highest level $(\mathrm{F}=7.47 \mathrm{MPa})$ was obtained from $\mathrm{Zr}$ groups, while the maximum principal stress at its lowest level $(\mathrm{F}=0.38 \mathrm{MPa})$ was obtained from FRP groups (Fig.5). 

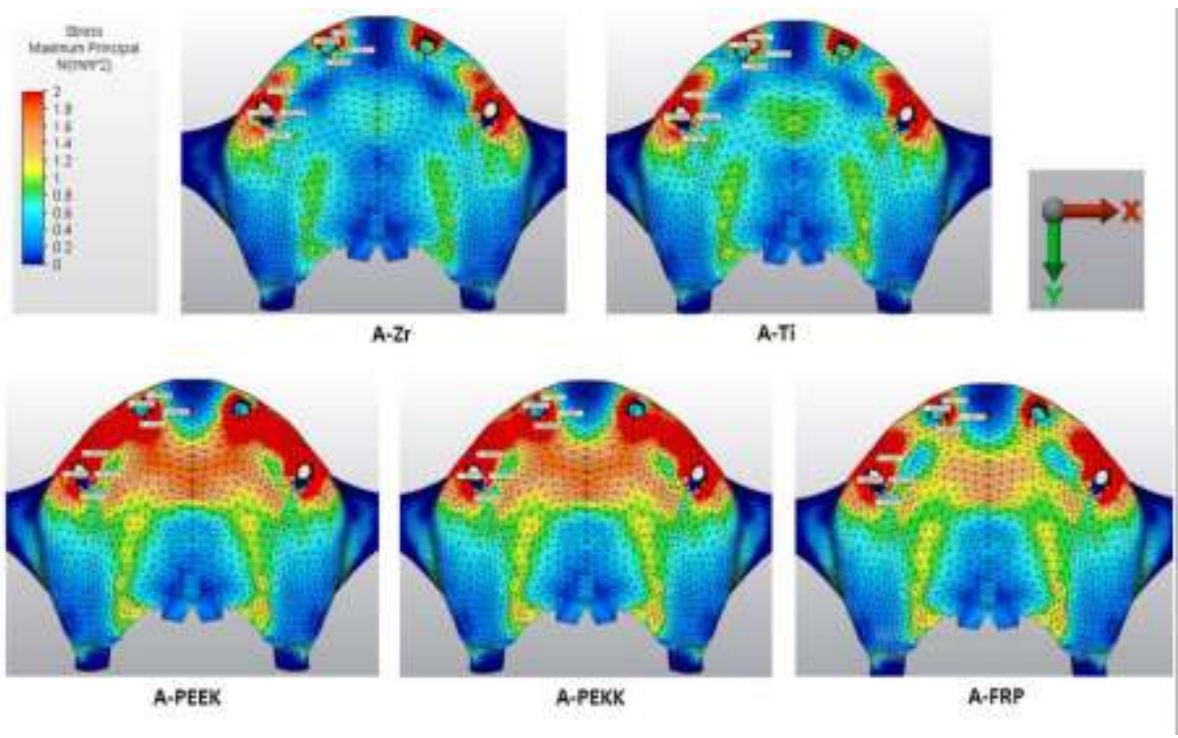

Fig.3. Maximum principal stress $\left(\sigma_{\max }\right)$ distribution $(\mathrm{MPa})$ in the cortical bone in acrylic groups
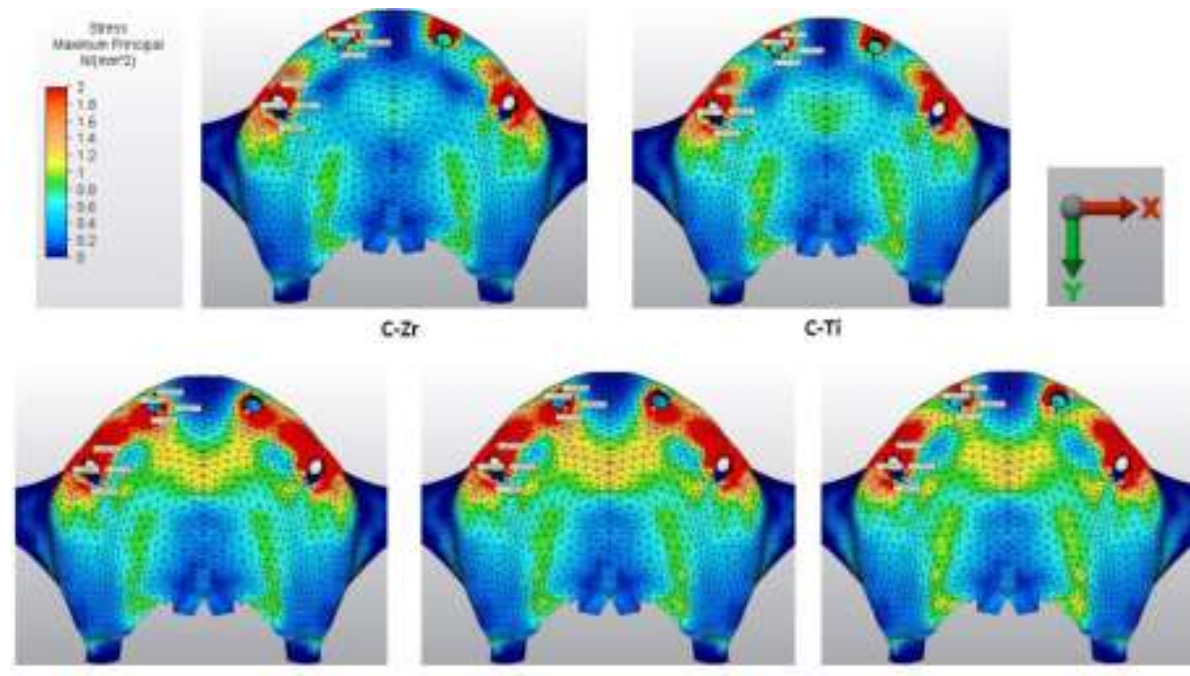

C.PEEX

c.PEKK

C.FRP

Fig.4. Maximum principal stress $\left(\sigma_{\max }\right)$ distribution $(\mathrm{MPa})$ in the cortical bone in composite groups
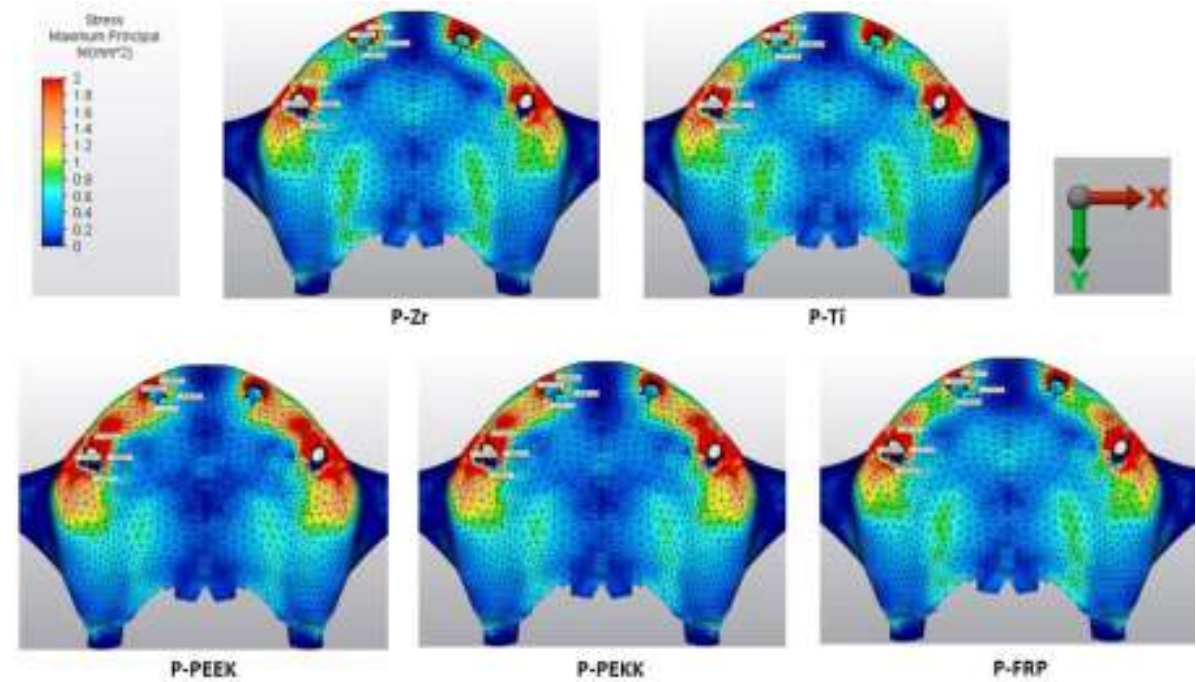

Fig.5. Maximum principal stress $\left(\sigma_{\max }\right)$ distribution $(M P a)$ in the cortical bone in porcelain groups 
In acrylic groups, the highest minimum principal stress $(\mathrm{F}=-32.13 \mathrm{MPa})$ was obtained in FRP groups, while the minimum principal stress at its lowest level $(\mathrm{F}=-0.36 \mathrm{MPa})$ was obtained from Ti groups (Fig.6). In composite groups, the highest minimum principal stress $(\mathrm{F}=-28.01 \mathrm{MPa})$ was obtained from FRP groups, while the minimum principal stress at its lowest level $(\mathrm{F}=-0.13 \mathrm{MPa})$ was obtained from PEEK groups (Fig.7). In porcelain groups, the highest minimum principal stress $(\mathrm{F}=-21.82$ $\mathrm{MPa}$ ) was obtained in $\mathrm{Ti}$ groups, while the minimum principal stress at its lowest level $(\mathrm{F}=$ $-0.18 \mathrm{MPa}$ ) was obtained from PEKK groups (Fig.8).
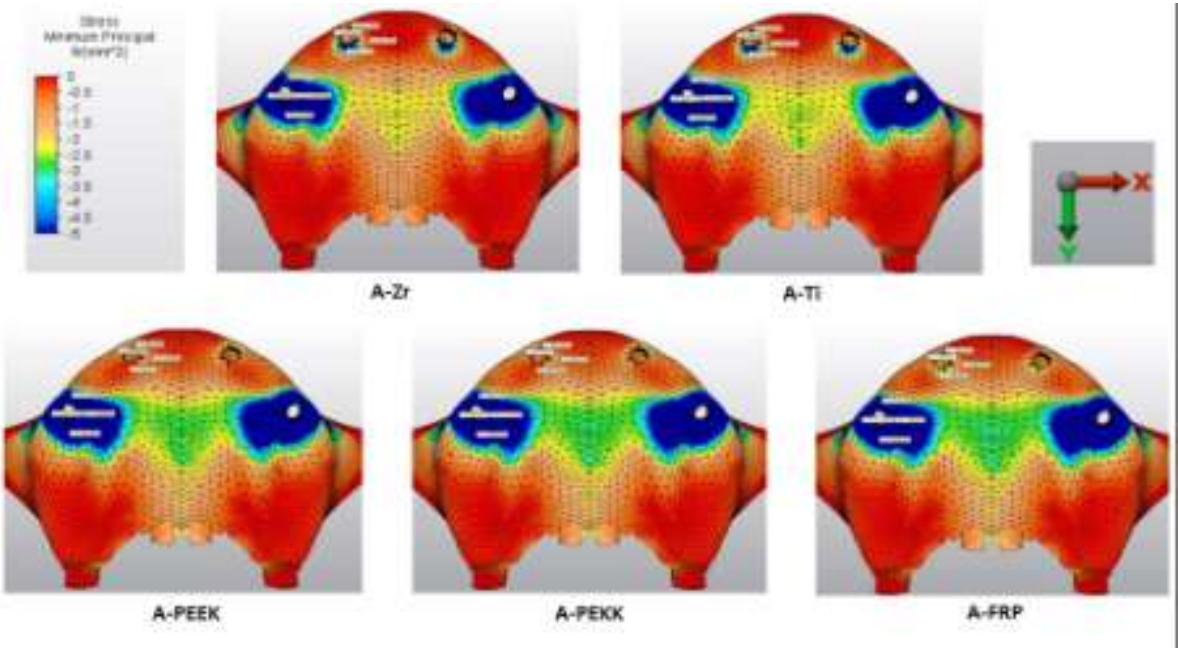

Fig.6. Minimum principal stress $\left(\sigma_{m i n}\right)$ distribution $(M P a)$ in the cortical bone in acrylic groups
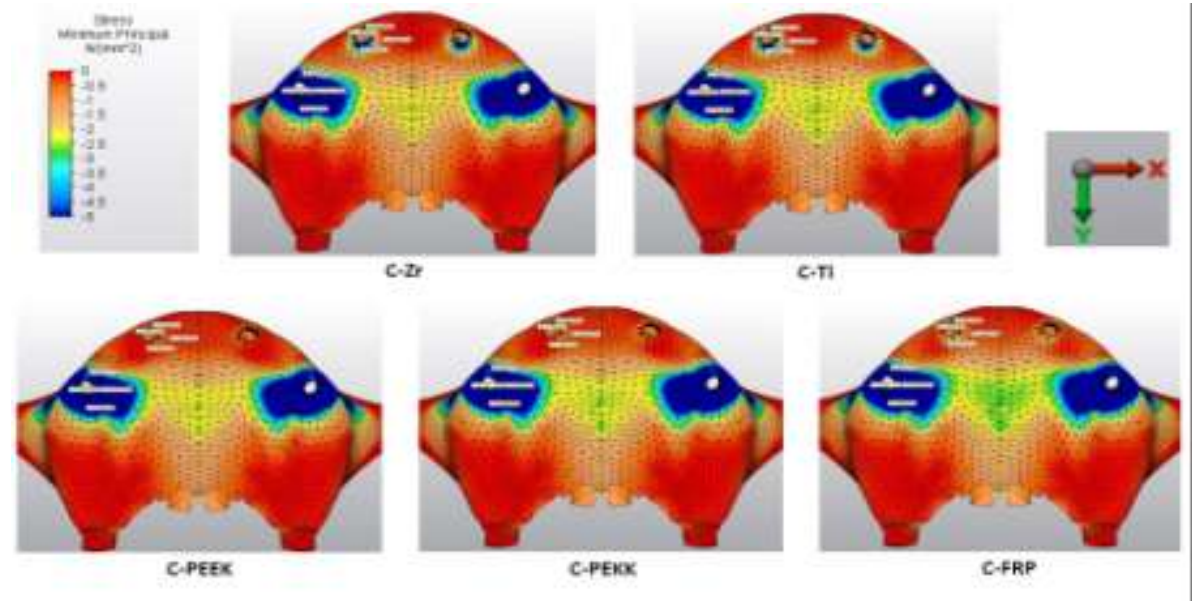

Fig.7. Minimum principal stress ( $\left.\sigma_{\min }\right)$ distribution $(\mathrm{MPa})$ in the cortical bone in composite groups
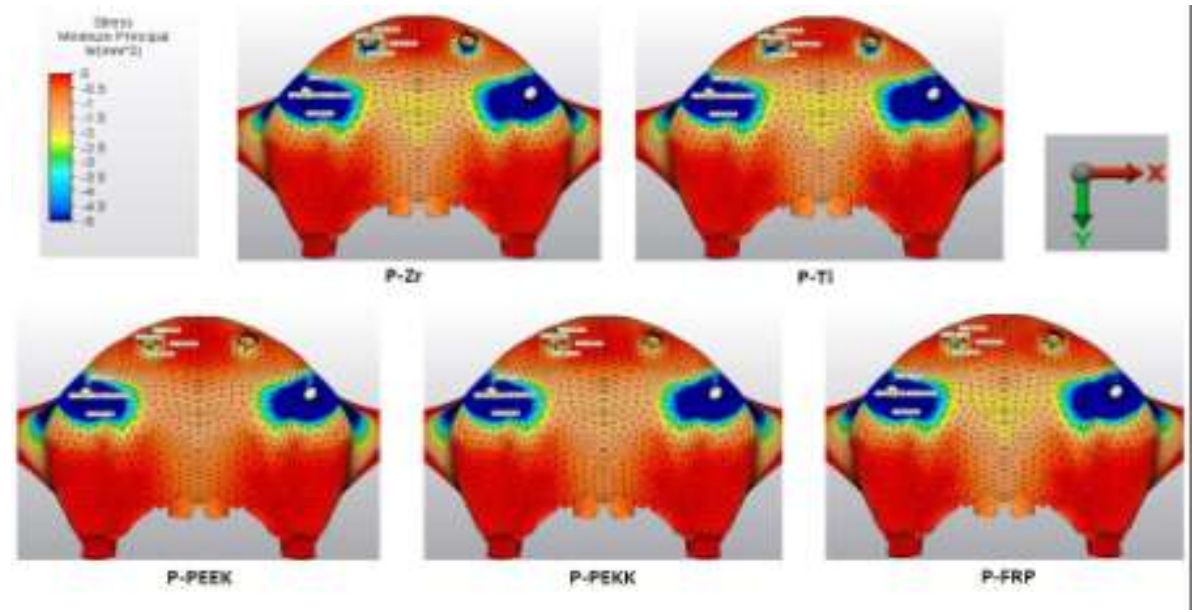

Fig.8. Minimum principal stress $\left(\sigma_{m i n}\right)$ distribution $(M P a)$ in the cortical bone in porcelain groups 


\subsection{Trabecular Bone}

In acrylic groups, the highest maximum principal stress $(\mathrm{F}=2.45 \mathrm{MPa})$ was obtained from FRP groups, while the maximum principal stress at its lowest level $(\mathrm{F}=0.11 \mathrm{MPa})$ was obtained from Ti groups (Fig.9). In composite groups, the highest maximum principal stress $(\mathrm{F}=2.18 \mathrm{MPa})$ was obtained in FRP groups,
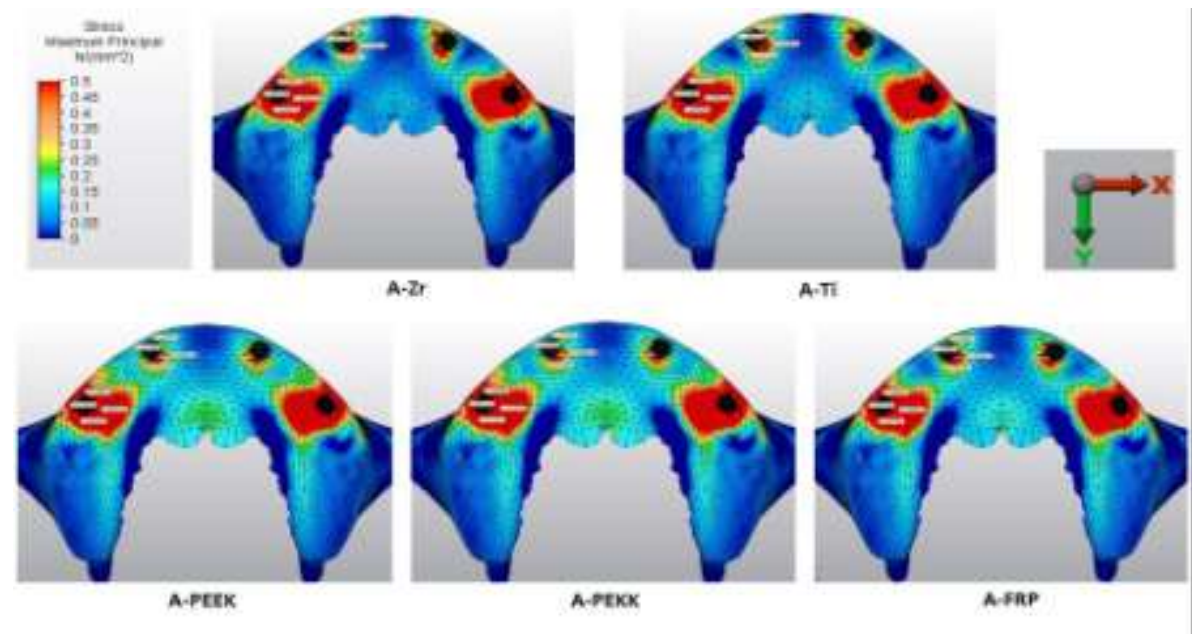

Fig.9. Maximum principal stress ( $\left.\sigma_{\max }\right)$ distribution $(\mathrm{MPa})$ in the trabecular bone in acrylic groups
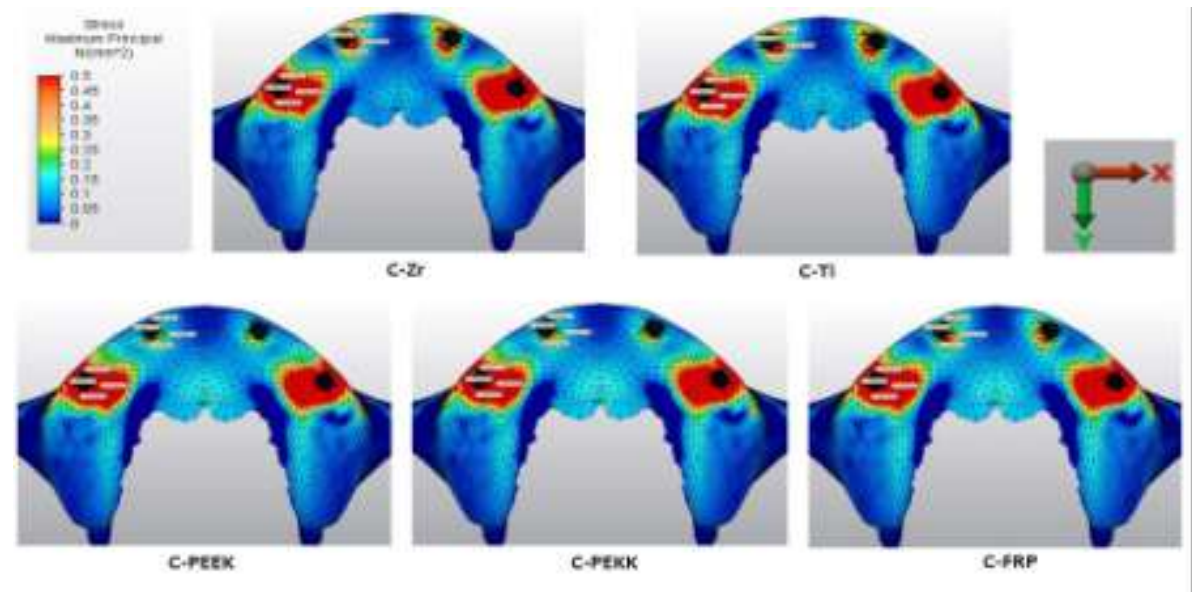

Fig.10. Maximum principal stress $\left(\sigma_{\max }\right)$ distribution $(\mathrm{MPa})$ in the trabecular bone in composite groups
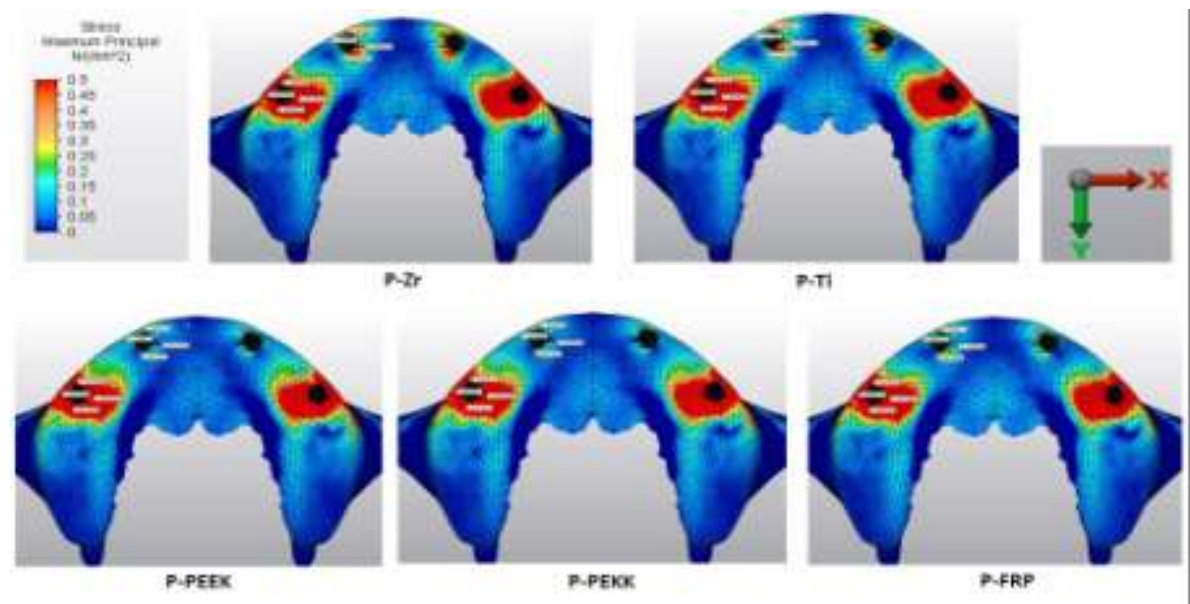

Fig.11. Maximum principal stress $\left(\sigma_{\max }\right)$ distribution $(\mathrm{MPa})$ in the trabecular bone in porcelain groups 
In acrylic groups, the highest minimum principal stress $(\mathrm{F}=-3.58 \mathrm{MPa})$ was obtained in PEEK groups, while the minimum principal stress at its lowest level $(\mathrm{F}=-0.25 \mathrm{MPa})$ was obtained from $\mathrm{Zr}$ groups (Fig.12). In composite groups, the highest minimum principal stress $(\mathrm{F}=-3.60 \mathrm{MPa})$ was obtained in FRP groups, while the minimum principal stress at its lowest level $(\mathrm{F}=-0.24 \mathrm{MPa})$ was obtained from $\mathrm{Zr}$ groups (Fig.13). In porcelain groups, the highest minimum principal stress $(\mathrm{F}=-3.91 \mathrm{MPa})$ was obtained from PEEK groups, while the minimum principal stress at its lowest level $(\mathrm{F}=$ $-0.14 \mathrm{MPa}$ ) was obtained from PEKK groups (Fig.14).
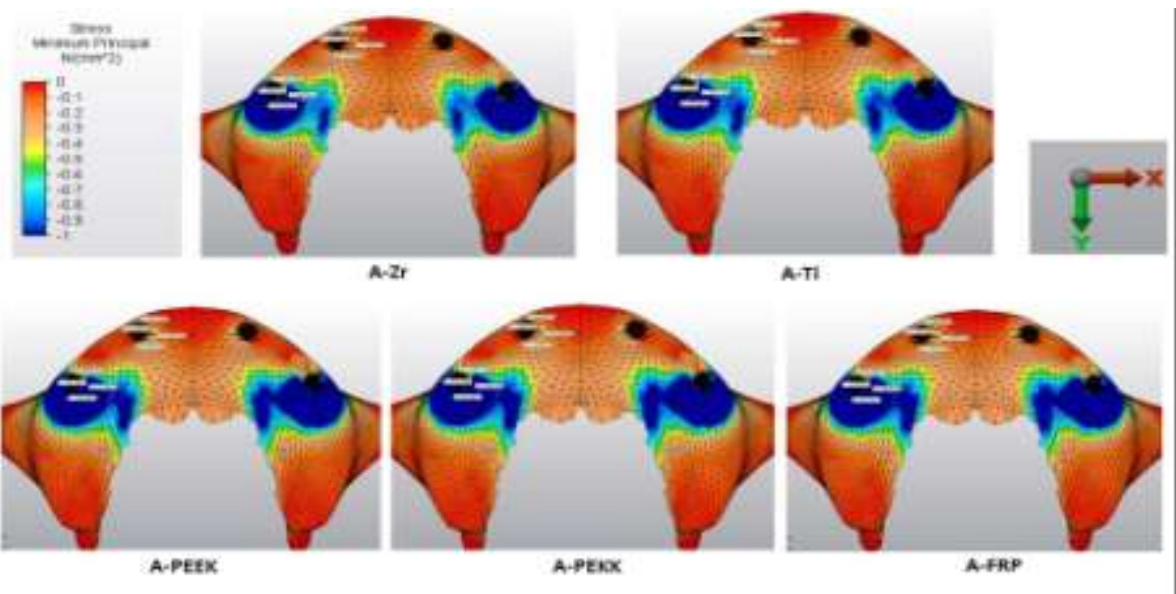

Fig.12. Minimum principal stress ( $\sigma \mathrm{min})$ distribution $(M P a)$ in the trabecular bone in acrylic groups
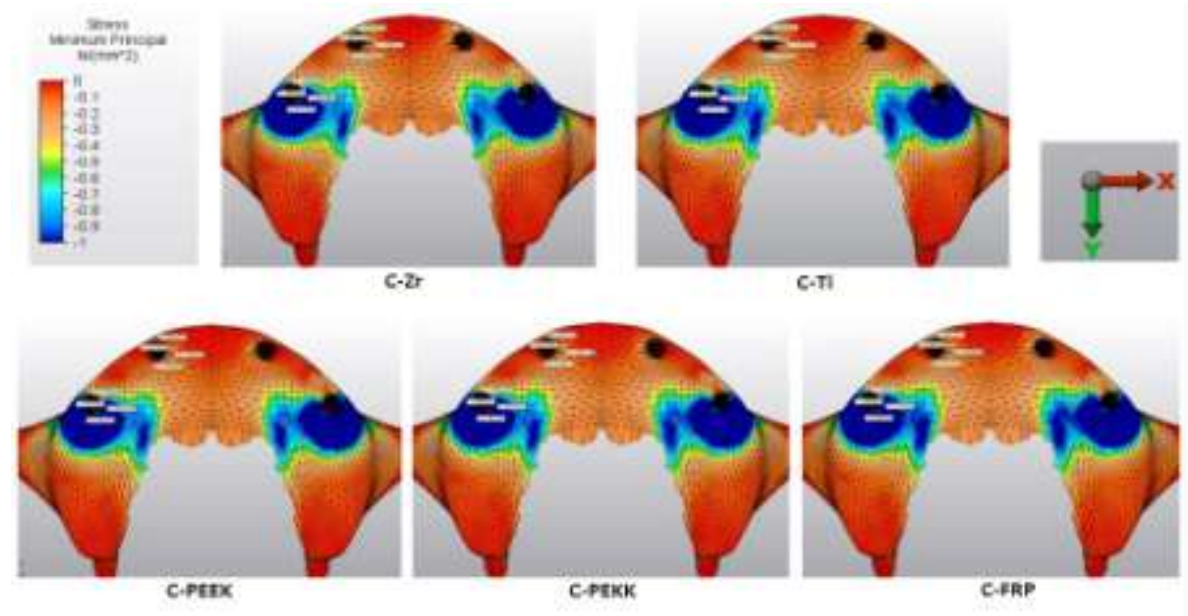

Fig.13. Minimum principal stress ( $\left.\sigma_{\mathrm{min}}\right)$ distribution $(\mathrm{MPa})$ in the trabecular bone in composite groups
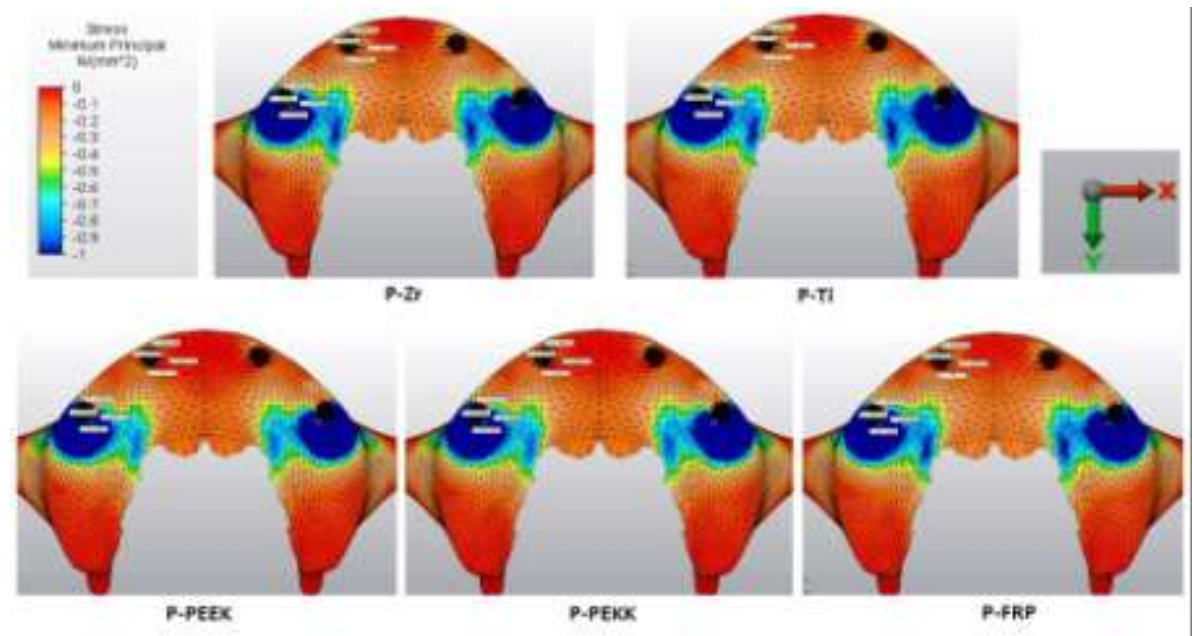

Fig.14. Minimum principal stress $\left(\sigma_{\text {min }}\right)$ distribution $(M P a)$ in the trabecular bone in porcelain groups 


\subsection{Implants}

In acrylic groups, von Mises stress $(\mathrm{F}=566.82$ $\mathrm{MPa})$ at its highest level was obtained from FRP groups, while von Mises stress at its lowest level $(\mathrm{F}=352.37 \mathrm{MPa})$ was obtained from $\mathrm{Zr}$ groups on posterior implants (Fig.15). In composite groups, von Mises stress at the highest level $(\mathrm{F}=$ 472.44 MPa) was obtained from FRP groups, while von Mises stress at the lowest level $(\mathrm{F}=$ $340.42 \mathrm{MPa}$ ) was obtained from $\mathrm{Zr}$ groups on posterior implants (Fig.16). In porcelain groups the highest von Mises stress $(\mathrm{F}=355.08 \mathrm{MPa})$ was obtained in FRP groups, while von Mises stress at the lowest level $(\mathrm{F}=303.64 \mathrm{MPa})$ was obtained from $\mathrm{Zr}$ groups on posterior implants (Fig.17).
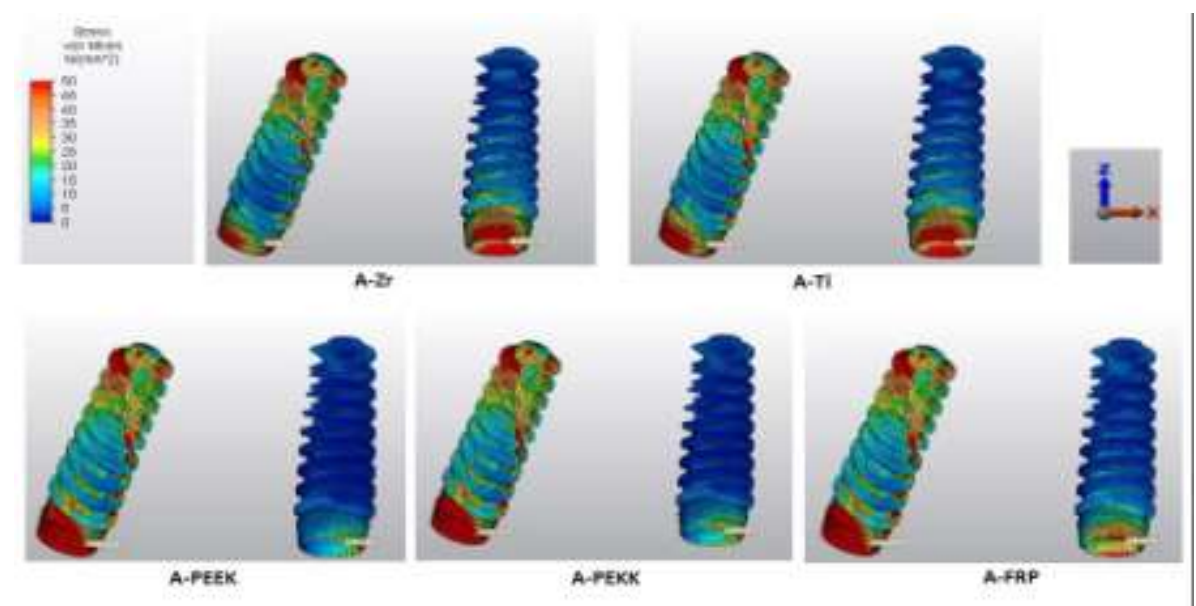

Fig.15. Von Mises stres $\left(\sigma_{v M}\right)$ distribution ( $\left.M P a\right)$ in implants in acrylic groups
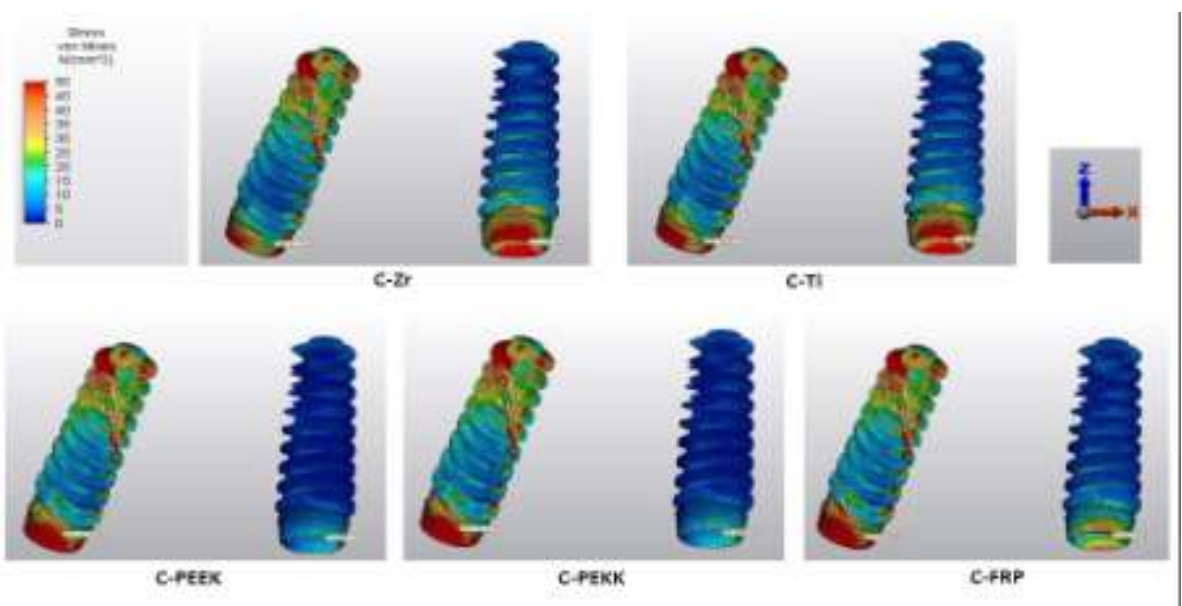

Fig.16. Von Mises stres $\left(\sigma_{v M}\right)$ distribution (MPa) in implants in composite groups
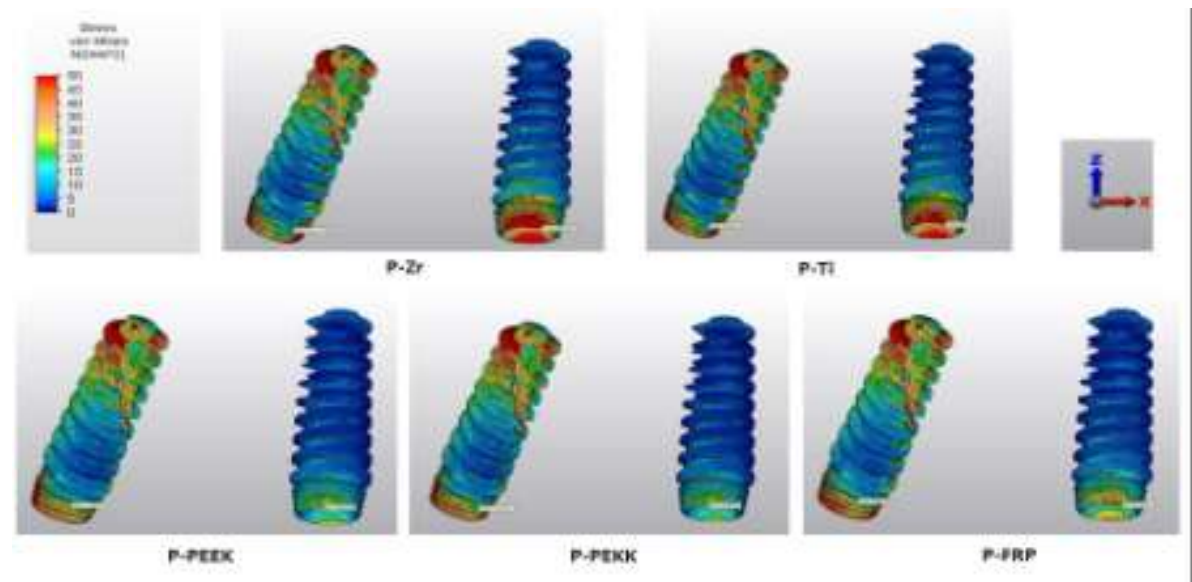

Fig.17. Von Mises stres $\left(\sigma_{v M}\right)$ distribution $(M P a)$ in implants in porcelain groups 


\subsection{Frameworks}

In acrylic groups, von Mises stress at the highest level $(\mathrm{F}=124.46 \mathrm{MPa})$ was obtained from $\mathrm{Zr}$ groups, while von Mises stress at the lowest level $(\mathrm{F}=124.03 \mathrm{MPa})$ was obtained from PEEK groups (Fig.18). In composite groups, von Mises stress at the highest level $(\mathrm{F}=126.17 \mathrm{MPa})$ was obtained from $\mathrm{Zr}$ groups, while von Mises stress at the lowest level $(\mathrm{F}=125.07 \mathrm{MPa})$ was obtained from PEEK groups (Fig.19). In porcelain groups, von Mises stress at the highest level $(\mathrm{F}=187.79 \mathrm{MPa})$ was obtained from PEEK groups, while von Mises stress at the lowest level $(\mathrm{F}=128.75 \mathrm{MPa})$ was obtained from FRP groups (Fig.20).
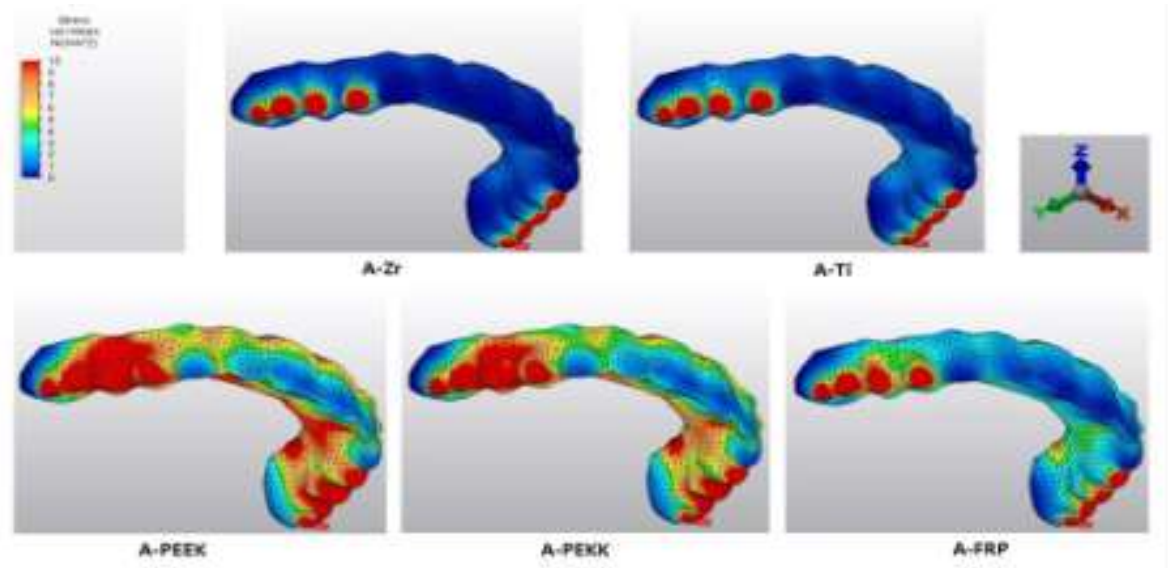

Fig.18. Von Mises stres $\left(\sigma_{v M}\right)$ distribution (MPa frameworks in) in acrylic groups
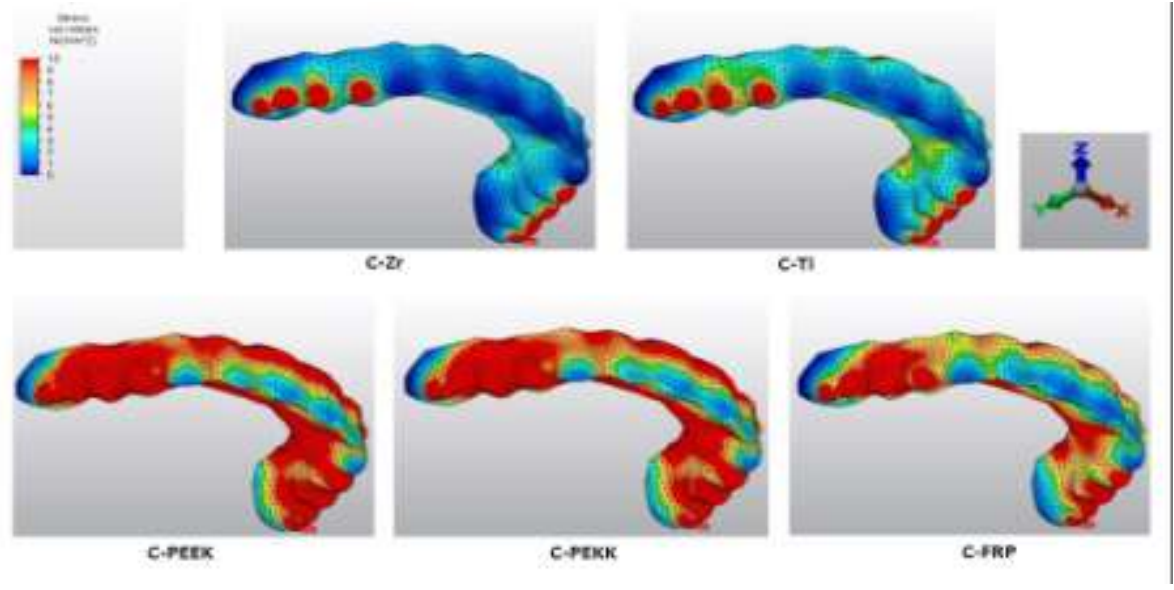

Fig.19. Von Mises stres $\left(\sigma_{v M}\right)$ distribution $(M P a)$ in frameworks in composite groups
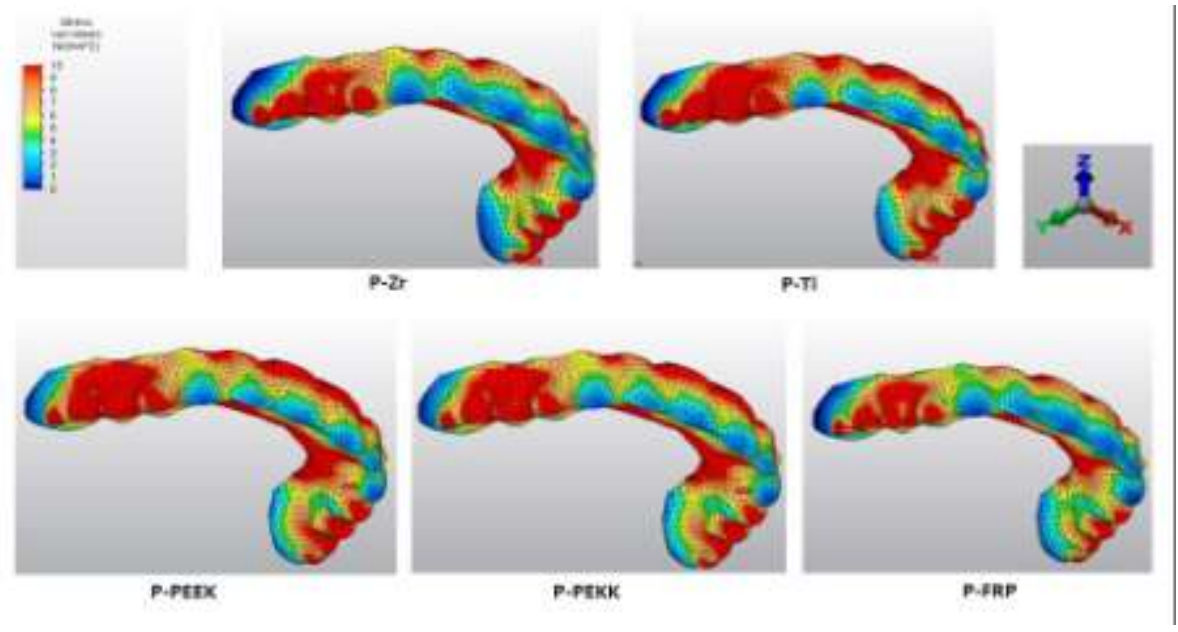

Fig.20. Von Mises stres $\left(\sigma_{v M}\right)$ distribution $(M P a)$ in frameworks in porcelain groups 


\section{DISCUSSION}

The present study views veneering materials and prosthetic framework as influential factors in terms of stress distribution. Taking into account the results obtained in the study, the tested hypothesis, which claims that the stress on the peri-implant area is under the effect of the veneering material and prosthetic framework of the different elasticity modulus, was accepted.

Whereas the tensile stress at its maximum is presented by the maximum principal stress, the compressive stress at its maximum is presented by the minimum principal stress. It is important to make sure that the stress values do not go higher than the maximum compressive and tensile strength of cortical bone, that is $173 \mathrm{MPa}$ and $100 \mathrm{MPa}$ correspondently [26, 27]. The present study uses the mentioned limits and makes sure that the obtained values do not exceed those limits as it can be pathologic to the bone tissue.

Ductile materials, in particular implants, undergo von Mises stress analysis with the obtained value that notifies about the start of permanent deformation. A failure is expressed with a value of von Mises stress $>550 \mathrm{MPa}$, that can be defined as the yield strength of the implant material $[28,29]$. In the present study three groups A-PEEK (551.63 MPa), A-PEKK (566.58 MPa) and A-FRP (566.82) exceeded these values. This finding supports previous studies that, not only the framework materials, also the veneering materials were determinant factors in the stress distribution. Such factors as high level of rigidity, high porcelain flexural strength, and high elastic modulus contribute to dissipation of stress, diminishing the hazards other structures can suffer from in terms of mechanical overload. The possible consequence of low elasticity modulus in acrylic resin can be higher level of deflection, in particular in the area of loading, thus producing greater stresses for the infrastructures $[24,30]$.

All in all, soft materials (FRP, PEEK, PEKK) demonstrated lower values of stress in comparison with those of stiffer materials (Ti and $\mathrm{Zr}$ ) in the prosthetic framework. Resistance level of high elastic modulus materials to deformation and bending is higher; thus, the stress values are also high. Use of materials with low-elastic modulus framework caused reduction in the framework stress; still, the periimplant bone and implants had more stress transferred by the framework. The efficiency of materials with low-elastic modulus framework in terms of shock absorbing was low. Under the functioning loads, the material with the framework of lower elastic modulus produced increased prosthesis bending with the subsequent higher bending forces that influence the implants. Typically, it was advantageous to use a rigid framework as it could diminish stress transmitted to the peri-implant bone and implants. It should be mentioned that the previous results agree with the results obtained on the topic in the present study [16-19,31,32].

Bilaterally oblique load of $30^{\circ}$ was applied in the present study because it has been reported that the approach generated by the oblique load to the implant-supported system is more effective than that with the horizontal or axial forces used in isolation [24,33,34]. Although some researchers applied forces unilaterally $[15,18,35]$, from the clinical point of view, masticatory muscles exert the forces which are applied bilaterally on the prosthetic components and implants.

In all groups, higher stress concentration points occurred very near to the loading area, as expected. As it was previously reported, the stress level in implants close to the loading area is higher as compared to others [36]. According to the previous reports, concentration of von Mises stress at its maximum in every loading situation was on the implant neck [5,37]. Concerning the pattern of stress distribution in the prosthetic framework, it is possible to assume that concentration of stress in the abutment seat base took place due to the contact interface between the abutment and the framework [15].

It was assumed that all materials used were isotropic, homogeneous, and linearly elastic, and the contact between the implant, bone, and interface of the implant and abutment was thorough $(100 \%)$. Despite no occurrences in clinical practice, these assumptions are typical for FEA studies because of the issues related to specifying the characteristics of living tissues and the level of osseointegration in the boneimplant surfaces. Such biologic simulations typically have limitations of this kind [15].

It is necessary to conduct further studies and research with simulation of various alternatives for the atrophic maxilla treatment with the involved dynamic forces which take place in the course of chewing, taking into account the regenerative and anisotropic bone properties. 
Moreover, the results of the present study should be confirmed in clinical practice with randomized clinical trials and longitudinal follow-up.

\section{CONCLusions}

The obtained results of the current study with the defined limitations make it possible to draw the following conclusions:

1. The factors of different veneering material and prosthetic framework with the different elasticity modulus produce a strong effect on the stress distribution.

2. As the elasticity modulus of the material used in the framework and veneering increased, the risk for long-term success and survival in the implant and surrounding tissues decreased.

3. The use of $\mathrm{Zr}$ and $\mathrm{Ti}$ materials in the framework and the porcelain in the veneering is more suitable.

\section{ACKNOWLEDGEMENTS}

Support to the study was given by Ondokuz May1s University Research Foundation (PYO.DIS.1904.18.007).

The authors report no conflicts of interest.

\section{REFERENCES}

[1] Krekmanov L, Kahn M, Rangert B, Lindström H. Tilting of posterior mandibular and maxillary implants for improved prosthesis support. Int J Maxillofacial Implants 2000;15 (3):405-414.

[2] Cidade CPV, Pimantel MJ, Do Amarol MJ, Nobilo MAA, Barbosa JRA. Photoelastic analyis of all-on-four concept using different implants angulations for maxilla. Braz Oral Res 2014;28:1-7.

[3] Lopes LFdTP, Da silva VF, Santiago Jr JF, Panzarini SR, Pellizzer EP. Placement of dental implants in the maxillary tuberosity: A sysytemic review. Int J Oral Maxillofac Sur 2015;44(2):229-238.

[4] Penarrocha-Oltra D, Candel-Marti E, Ata-Ali J, Penarrocha-Diago M. Rehabilitation of the atrophic maxilla with tilted implants: Review of the literatüre. J Oral Implantol 2013;39(5):625632.

[5] Silva GC, Mendonça JA, Lopes LR, Landre J Jr. Stress patterns on implants in prostheses supported by four or six implants: a threedimensional finite element analysis. Int J Oral Maxillofac Implants 2010;25(2):239-246.
[6] Aparicio C, Perales P, Rangert B. Tilted implants as an alternative to maxillary sinüs grafting:A clinical, radiologic, and Periotest study. Clin Implant Dent Relat Res 2001;3(1):39-49.

[7] Almeida EO, Rocha EP, Freitas-Junior AC, Anchieta RB, Poveda R, Gupta N Coelho PG. Tilted and short implants supporting fixed prosthesis in an atrophic maxillae. Clin Implant Dent Relat Res. 2015 Jan;17 Suppl 1:e332-42.

[8] Maló P, Rangert B, Nobre M. All-on-4 immediate-function concept with Branemark system implants for completely edentulous maxillae:A 1-year retrospective clinical study. Clin Implant Dent Relat Res 2005;7:88-94.

[9] Maló P, de Araujo NM, Lopes A, Francischone C, Rigolizzo M. 'All-on-four' immediatefunction concept for completely edentulous maxillae: a clinical report on the medium (3 years) and long-term (5 years) outcomes. Clin Implant Dent Relat Res 2012;14:e139-e150.

[10] Testori, T, Del Fabbro M, Capelli M, Zuffetti F, Francetti L, Weinstein RL. Immediate occlusal loading and tilted implants for the rehabilitation of the atrophic edentulous maxilla: 1-year interim results of a multicenter prospective study. Clin Oral Implants Res 2008;19(3):227232.

[11] Agnini A, Agnini AM, Romeo D, Chiesi M, Pariente L, Stappert CF. Clinical investigation on axial versus tilted implants for immediate fixed rehabilitation of edentulous arches: preliminary results of a single cohort study. Clin Implant Dent Relat Res 2014;16(4):527539.

[12] Patzelt SB, Bahat O, Reynolds MA, Strub JR. The all-on-four treatment concept: a systematic review. Clin Implant Dent Relat Res 2014;16(6):836-855.

[13] Lopes A, Maló P, de Araújo Nobre M, Sánchez-Fernández E, Gravito I. The NobelGuide ${ }^{\circledast}$ All-on- $4{ }^{\circledR}$ Treatment Concept for Rehabilitation of Edentulous Jaws: A Retrospective Report on the 7-Years Clinical and 5-Years Radiographic Outcomes. Clin Implant Dent Relat Res 2017;19(2):233-244.

[14] Maló P, de Araújo Nobre M, Lopes A, Ferro A, Nunes M. The All-on-4 concept for full-arch rehabilitation of the edentulous maxillae: a longitudinal study with 5-13 years of followup. Clin Implant Dent Relat Res 2019;21(4):538-549.

[15] Bhering CLB, Mesquita MF, Kemmoku DT, Noritomi PY, Consani RLX, Barão VAR. Comparison between all-on-four and all-on-six treatment concepts and framework material on stress distribution in atrophic maxilla: A 
prototyping guided 3D-FEA study. Materials Science and Engineering C 2016;69:715-725.

[16] Bacchi A, Consani RL, Mesquita MF, Dos Santos MB. Stress distribution in fixed-partial prosthesis and peri-implant bone tissue with different framework materials and vertical misfit levels: a three-dimensional finite element analysis. Int J Dent Oral Sci 2013;55(3):239244.

[17] Sirandoni D, Leal E, Weber B, Noritomi PY, Fuentes R, Borie E. Effect of different framework materials in implant-supported fixed mandibular prostheses: A finite element analysis. Int $\mathbf{J}$ Oral Maxillofac Implants 2019;34(6):e107-e114.

[18] Menini M, Pesce P, Bevilacqua M, Pera, F, Tealdo, T, Barberis F, Pera P. Effect of framework in an implant-supported full-arch fixed prosthesis: $3 \mathrm{~d}$ finite element analysis. Int J Prosthodont 2015;28(6):627-630.

[19] Lee KS, Shin SW, Lee SP, Kim JE, Kim JH, Lee JY, Lee KS, Shin SW, Lee SP, Kim JE. Comparative evaluation of a four-implantsupported polyetherketoneketone framework prosthesis: a three-dimensional finite element analysis based on cone beam computed tomography and computer-aided design. Int $\mathbf{J}$ Prosthodont 2017;30(6):581-585.

[20] Zoidis P. The all-on-4 modified polyetheretherketone treatment approach: A clinical report. J Prosthet Dent 2018; 119(4):516-521.

[21] Seeman R, Marincola M, Seay D, Perisanidis C, Barger N, Ewers R. Preliminary results of fixed, fiber-reinforced resin bridges on four 45-mm ultrashort implants in compromised bony sites: A pilot study. J Oral Maxillofac Surg 2015;73(4):630-640.

[22] Wagner F, Seeman R, Marincola M, Ewers R. Fiber-reinforced resin fixed prostheses on 4 short implants in severely atrophic maxillas: 1year results of a prospective cohort study. J Oral Maxillofac Surg 2018;76(6):1194-1199.

[23] Han KH, Lee JY, Shin SW. Implant-and toothsupported fixed prostheses using a highperformance polymer (Pekkton) framework. Int J Prosthodont 2016;29(5):451-454.

[24] Ferreira MB, Barão VA, Faverani LP, Hipolito AC, Assuncao WG. The role of superstructure material on the stress distribution in mandibular full-arch implant-supported fixed dentures. A CT-based 3D-FEA. Mater Sci Eng C Mater Biol Appl 2014;35:92-99.

[25] Pesqueira AA, Goiato MC, Filho HG, Monteiro DR, Santos DMd, Haddad MF, Pellizzer EP. Use of stress analysis methods to evaluate the biomechanics of oral rehabilitation with implants. J Oral Implantol 2014;40(2):217-228.
[26] Reilly DT, Burstein AH. The elastic and ultimate properties of compact bone tissue. J Biomech 1975;8(6):393-405.

[27] Akça K, Íplikçioğlu H. Finite element stress analysis of the influence of staggered versus straight placement of dental implants. Int J Oral Maxillofac Implants 2001;16(5):722730.

[28] Akça K, Íplikçioğlu H. Finite element stress analysis of the effect of short implant usage in place of cantilever extensions in mandibular posterior edentulism. J Oral Rehabil 2002;29(4):350-356.

[29] Öztürk Ö, Külünk T, Külünk Ş. Influence of different implant-abutment connections on stress distribution in single tilted implants and peripheral bone: A three-dimensional finite element analysis. Biomed Mater Eng 2018;29(4):513-526.

[30] Ferreira MB, Barão VA, Delben JA, Faverani LP, Hipólito AC, Assunção WG. Non-linear 3D finite element analysis of full-arch implantsupported fixed dentures. Mater Sci Eng C Mater Biol Appl 2014;38:306-314.

[31] Jacques LB, Moura MS, Suedam V, Souza EAC, Rubo JH. Effect of cantilever length and framework alloy on the stress distribution of mandibular-cantilevered implant-supported prostheses. Clin Oral Implan Res 2009;20(7):737-741.

[32] Assunção WG, Gomes EA, Barao VAR, Delben JA, Tabata LF, de Sousa EAC. Effect of superstructure materials and misfit on stress distribution in a single implant-supported prosthesis: a finite element analysis. J Craniofac Surg 2010;21(3):689-695.

[33] Falcón-Antenucci RM, Pellizzer EP, de Carvalho PS, Goiato MC, Noritomi PY. Influence of cusp inclination on stress distribution in implant-supported prostheses. A three-dimensional finite element analysis. J Prosthodont 2010;19(5):381-386.

[34] Tabata LF, Rocha EP, Barão VA, Assunção WG. Platform switching: biomechanical evaluation using three-dimensional finite element analysis. Int J Oral Maxillofac Implants 2011;26(3):482-491.

[35] Ozan O, Kurtulmus-Yilmaz S. Biomechanical comparison of different implant inclinations and cantilever lengths in All-on-4 treatment concept by three-dimensional finite element analysis. Int $\mathbf{J}$ Oral Maxillofac Implants. 2018;33(1):64-71.

[36] Almeida EO, Rocha EP, Freitas Júnior AC, Anchieta RB, Poveda R, Gupta N, Coelho PG. Tilted and short implants supporting fixed prosthesis in an atrophic maxilla: a 3D-FEA biomechanical evaluation. Clin Implant Dent Relat Res 2015;17 Suppl 1:e332-e342. 
Evaluation of the Prosthetic Alternatives on Stress Distribution in Atrophic Maxilla in all-on-Four Treatment Concept: A Three-Dimensional Finite Element Analysis

[37] Bellini CM, Romeo D, Galbusera F, Agliardi E, Pietrabissa R, Zampelis A, Francetti L. A finite element analysis of tilted versus nontilted implant configurations in the edentulous maxilla. Int J Oral Implantol 2009;22(2):155157.

Citation: Sefa Kılıç, Tolga Külünk, Şafak Külünk. "Evaluation of the Prosthetic Alternatives on Stress Distribution in Atrophic Maxilla in all-on-Four Treatment Concept: A Three-Dimensional Finite Element Analysis". ARC Journal of Dental Science. 2021; 6(1):16-28. DOI: https://doi.org/10.20431/24560030.0601004.

Copyright: (C) 2021 Authors. This is an open-access article distributed under the terms of the Creative Commons Attribution License, which permits unrestricted use, distribution, and reproduction in any medium, provided the original author and source are credited. 